\title{
María Soledad González, Victoria Ocampo. Escritura, poder y representaciones. Rosario, Prohistoria, 2018, 182 págs.
}

A cuarenta años del fallecimiento de Victoria Ocampo y en un contexto de avance a nivel mundial de la lucha por los derechos de las mujeres, la obra biográfica escrita por María Soledad González se torna de lectura imprescindible. Desde una perspectiva de análisis que atiende al género y a la clase social, Victoria Ocampo. Escritura, poder y representaciones constituye un valioso aporte para la historia de los intelectuales en América Latina.

Esta personalidad crucial de la cultura argentina del siglo XX es abordada por la autora en su triple dimensión de mujer, intelectual y miembro de la élite porteña, considerando los límites, pero también las posibilidades que aquellas condiciones imprimieron a su accionar. De esta manera, se vuelve posible analizar la subjetividad de Victoria Ocampo, esto es, sus miedos, logros y frustraciones.

La experiencia de vida de la biografiada, como se observa en las páginas del libro, estuvo marcada en gran parte por su posición de primogénita mujer en un universo patriarcal, lidiando desde la infancia con el fantasma del hijo varón no nacido y desarrollando una serie de estrategias para superar aquellas dificultades a partir de las ventajas que le otorgaba ser parte de una de las familias más ricas de la ciudad.

El trabajo de María Soledad González toma una periodización de tres momentos históricos que enlazan el derrotero de la élite liberal conservadora con la intervención pública de Victoria Ocampo: en primer lugar, la interrupción democrática durante la década de 1930; en segundo lugar, la irrupción del peronismo en la década siguiente; en tercer lugar, la última dictadura cívico-militar en Argentina, durante los años setenta.

A partir de la intersección de la historia intelectual con la historia política, la historia social y la historia cultural, la autora reconstruye las tramas relacionales en las que Victoria Ocampo se insertó para desarrollar posteriormente la empresa de su vida: la creación y permanencia de la revista y también editorial Sur, una de las más influyentes del campo cultural argentino y latinoamericano del siglo pasado.

Desde allí, se propuso educar y civilizar a la patria o hacerla, según habían marcado sus antepasados. Las letras fueron para ella una herramienta de legitimación y de poder que le permitió pre- 
sentarse como el punto de llegada y continuación de una genealogía familiar emparentada con la historia del país desde la época colonial, aun cuando su hermana menor Silvina experimentara mayores éxitos como escritora.

Ahora bien, no cualquiera podía disponer del capital económico, social y cultural para emprender una tarea de aquellas características, lo cual demuestra que contaba con recursos a los que mujeres de las clases populares no podían acceder. El interrogante, entonces, que atraviesa la investigación es el siguiente: ¿utilizó Victoria estas ventajas para luchar en beneficio de un colectivo feminista o fueron sólo un trampolín para cumplir con ambiciones y objetivos exclusivamente personales?

La respuesta es una de las hipótesis que puede generar más controversias, al discutir con las imágenes heredadas de la historiografía feminista más tradicional. Según la autora, Victoria Ocampo no fue una militante activa por los derechos de las mujeres ni salió jamás de los marcos impuestos por su clase. Por el contrario, en su afán por alcanzar la trascendencia, anheló de forma permanente la aceptación de aquellos varones que dominaban el campo cultural argentino y latinoamericano.

Dichas definiciones están sustentadas en un exhaustivo análisis de fuentes escritas por Victoria Ocampo: la Autobiografía y los Testimonios, relativas al ámbito público, y la Correspondencia con Gabriela Mistral (1926-1956) y las Cartas de posguerra, pertenecientes a la vida privada. Mientras las primeras están elaboradas cuidadosamente, buscando la auto representación intelectual en la vida nacional, el carácter de las segundas las torna más crudas y menos filtradas en cuanto a ciertos prejuicios sociales y posicionamientos políticos.

Por ello, conviene finalizar esta reseña señalando dos cuestiones que me parecen cruciales para valorar la obra de María Soledad González. Por un lado, la importancia de rastrear a través del estudio de mujeres del pasado la existencia o no de aportes a una lucha feminista emancipatoria que tiene larga data y continúa hasta el presente, además de reflexionar sobre los límites que pueda tener si esta no se sustenta en una base democrática y popular. Por último y como sostiene en el prólogo Valeria Silvina Pita, destacar la valentía de una autora que se arriesga a afirmar, en tiempos donde los interrogantes y las dudas suelen ser la moneda corriente.

Renzo Sanfilippo

Becario Doctoral-Conicet Universidad Nacional de Rosario 